\title{
Yield and quality of sunflower oil in Ultisol and Oxisol under water regimes
}

\author{
Luis H. Loose ${ }^{1}$, Arno B. Heldwein² ${ }^{2}$ Jocélia R. da Silva ${ }^{3}$ \& Mateus P. Bortoluzzi ${ }^{4}$
}

${ }^{1}$ Instituto Federal Farroupilha, Santo Ângelo, RS, Brasil. E-mail: luis.loose@iffarroupilha.edu.br (Corresponding author) - ORCID: 0000-0002-9607-8798

${ }^{2}$ Universidade Federal de Santa Maria/Departamento de Fitotecnia, Santa Maria, RS, Brasil. E-mail: heldweinab@smail.ufsm.br - ORCID: 0000-00033738-7512

${ }^{3}$ Universidade Federal de Santa Maria/Programa de Pós-Graduação em Agronomia, Santa Maria, RS, Brasil. E-mail: joceliarosa.s@gmail.com - ORCID: 0000-0003-4446-4184

${ }^{4}$ Universidade de Passo Fundo/Faculdade de Agronomia e Medicina Veterinária, Passo Fundo, RS, Brasil. E-mail: mateusbortoluzzi@hotmail.com ORCID: 0000-0002-7257-5802

ABSTRACT: Extreme natural events influencing soil water availability are major factors limiting yield and oil quality in oilseed crops. The aim of the present study was to assess the effect of water deficit and surplus water on yield, oil content and on the fatty acid profile of sunflower plants sown in main and second crop seasons in two soil classes in Rio Grande do Sul State. The experiment was carried out in Santa Maria, RS (Ultisol) and Panambi, RS state, Brazil (Oxisol), Brazil, and comprised three water conditions (water deficit, water surplus and control) in a randomized block design. The hybrid Helio 250 was sown in early September (main crop season) and in early January (second crop season) in both soil classes. Yield, yield components, oil content, oil yield and fatty acid profile were herein analyzed. Yield and yield components were affected by water conditions, sowing dates and soil class. The soil class had no significant effect on oil content, yield or quality. Water deficit was more harmful to oil yield and quality than water surplus. Water deficit was responsible for increased oleic fatty acid contents and for linoleic content reduction.

Key words: Helianthus annuus L., water stress, fatty acids

\section{Produtividade e qualidade do óleo de girassol em Argissolo e Latossolo sob regimes hídricos}

RESUMO: Eventos naturais extremos que influenciam a disponibilidade hídrica no solo são os principais fatores limitantes da produtividade e da qualidade do óleo das culturas oleaginosas. O objetivo do presente trabalho foi avaliar o efeito do déficit e do excesso hídrico sobre a produtividade, o teor de óleo e o perfil de ácidos graxos do girassol cultivado na Safra e na Safrinha em dois solos do Rio Grande do Sul. O experimento foi conduzido em Santa Maria, RS (Argissolo) e Panambi, RS (Latossolo), e compreende três condições hídricas (déficit hídrico, excesso hídrico e controle) no delineamento de blocos ao acaso. O híbrido Helio 250 foi semeado no início de setembro (Safra) e início de janeiro (Safrinha) em ambos os solos. A produtividade, os componentes de rendimento, o teor de óleo, o rendimento de óleo e o perfil de ácidos graxos foram as variáveis analisadas. A produtividade e os componentes de rendimento foram afetados pela condição hídrica, pela época de semeadura e pela classe de solo. O fator classe de solo não teve efeito significativo sobre o teor e o rendimento de óleo ou qualidade. O déficit hídrico foi mais prejudicial para o rendimento e a qualidade do óleo do que o excesso hídrico. O déficit hídrico foi responsável pelo aumento do ácido oleico e redução do ácido linoleico.

Palavras-chave: Helianthus annuus L., estresse hídrico, ácidos graxos 


\section{INTRODUCTION}

Sunflower (Helianthus annuus L.) is rich in unsaturated long-chain fatty acids (Connor \& Sadras, 1992). Most of it is raw material for cooking-oil manufacturing, but part of it is also used for animal feed and biodiesel production (Spinelli et al., 2012).

Sunflower yield is highly correlated to water conditions in the soil. Different water deficit or water surplus intensity depends on location, rainfall regime and weather conditions in the sowing date (Heldwein et al., 2014). Extreme natural events influencing water availability reduce yield, and may affect oil content and fatty acid profile (Flagella et al., 2002; Sezen et al., 2011; Yasumoto et al., 2011).

Water deficit leads to leaf wilting, a significant reduction of stomatal conductance and reduction of transpiration as the first symptoms in sunflower plants (Gholinezhad \& Sajedi, 2012); consequently, decreases the photosynthetic rate, grain filling, yield (Karam et al., 2007) and oil content.

Water surplus leads to stomatal closure, reduction in chlorophyll and protein rates, drastic reduction of photosynthesis, decreased leaf expansion and growth, leaf senescence, changes in grain filling rate, reduced root biomass, yield (Grassini et al., 2007) and oil content (Flagella et al., 2002; Sezen et al., 2011; Jalilian et al., 2012).

Water deficit leads to oleic/linoleic ratio increase (Flagella et al., 2002; Sezen et al., 2011), whereas water surplus reduces the oleic/linoleic ratio (Yasumoto et al., 2011). However, air temperature has the greatest influence on the fatty acid profile of sunflower (Connor \& Sadras, 1992). The aim of this article was to assess water deficit and water surplus effect on the yield, oil content and fatty acid profile of sunflower sown in main and second crop seasons and grown in two soil classes (Ultisol and Oxisol) in Rio Grande do Sul state, Brazil.

\section{Material ANd Methods}

The experiment was carried out in Santa Maria (latitude: $29^{\circ} 43^{\prime} 23^{\prime \prime}$ S; longitude: $53^{\circ} 43^{\prime} 15^{\prime \prime} \mathrm{W}$; altitude: $95 \mathrm{~m}$ ) and Panambi (latitude: $28^{\circ} 16^{\prime} 2^{\prime \prime}$ S; longitude: $53^{\circ} 34^{\prime} 43^{\prime \prime} \mathrm{W}$; altitude: $419 \mathrm{~m}$ ), Rio Grande do Sul state, Brazil. The soil in Santa Maria experimental site is an Ultisol, sandy in first $0.50 \mathrm{~m}$, with a textural B horizon below. The soil in the Panambi experimental site is an Oxisol, with a B horizon highly clayey. The climate in both regions is classified as humid subtropical (Cfa), with prevalence of water surplus periods in winter and early spring, and without drought periods.

After saturation, moisture and the drainage curve of each soil were determined. Soil samples were collected from layers $0.05 \mathrm{~m}$ deep every $12 \mathrm{~h}$ until completing a $72-\mathrm{h}$ cycle in order to find field moisture capacity after drainage curve stabilization. The permanent wilting point of each soil layer was determined using a WP4 device (tension set at 1.5 MPa).

Sunflower plants were sown using the no tillage method in main crop season (early September) and second crop season (early January) in Santa Maria (Sept. 6, 2013; Jan. 6, 2014 and Jan. 6, 2015) and in Panambi (Sept. 7, 2013 and Jan. $7,2014)$. The spacing of $0.50 \mathrm{~m}$ between rows and of $0.45 \mathrm{~m}$ between plants (after thinning) was adopted, and it resulted in a population of 44,444 plants ha-1. At sowing NPK (5-20-20) fertilization was applied using 300 and $30 \mathrm{~kg} \mathrm{ha}^{-1}$ Borax. $220 \mathrm{~kg} \mathrm{ha}^{-1}$ of urea were applied at the V10 stage. Other cultural practices were carried out according to technical indications for sunflower cultivation.

The experiment was carried out in randomized block design, with four repetitions, in a factorial scheme with three factors $(3 \times 2 \times 2)$, namely: three water availability conditions, control, water deficit and water surplus; two sowing dates, main and second crop seasons; and two soil classes, Ultisol and Oxisol. The plots were $22 \mathrm{~m}^{2}$.

The adopted water availability treatments were: water deficit - irrigation was kept bellow the rates needed for the crop, storage was kept between 40 to $60 \%$ of the available water capacity (AWC); control - best water availability conditions to the plants, storage was kept between 75 and 100\% of AWC in order to avoid water surplus and water deficit; water surplus soil irrigation was performed until reaching surplus conditions and complete saturation, storage was kept at rates higher than $90 \%$ of AWC, irrigation was performed until reaching soil saturation. Water treatments started at V6 stage, and rain entry was limited in plots subjected to water deficit.

The soil water condition was set through the sequential water balance (SWB) by Thornthwaite-Mather at daily scale, adapted by Dourado Neto et al. (1999) for the AWC of each soil class. According to Dourado Neto et al. (1999), AWC changes throughout the cycle due to root growth; they proposed an initial AWC and a final AWC. The crop does not have deep roots at the beginning of the cycle, thus sunflower plants only use water from the surface layer ( $0.10 \mathrm{~m}$ deep). After development, the sunflower reaches greater depths of roots, resulting in a greater layer of soil explored by the roots ( $0.60 \mathrm{~m}$ deep).

Meteorological data were collected at the Santa Maria and Cruz Alta automatic weather stations of Instituto Nacional de Meteorologia (INMET) in RS state, Brazil, which are, respectively, 0.1 and $30 \mathrm{~km}$ away from the experimental sites. Rainfall data were collected at the experimental sites by using pluviometers; next, they were adjusted to effective precipitation through curve numbers (CN) 62 and 82, for Ultisol and Oxisol, respectively. The $\mathrm{CNs}$ were defined according to soil texture and use. Reference evapotranspiration (ETo) was calculated using the Penman-Monteith method; radiation rate was adjusted in the Brunt-Penman equation suggested by Righi et al. (2015). The evapotranspiration was calculated through the equations described by Allen et al. (1998).

The water deficit treatment had a wooden structure like a plastic greenhouse, which allowed low density polyethylene (LDPE) plastic film placement and removal right before and after each rainfall event, respectively, in order to prevent soil moisture from reaching rates higher than $60 \%$ of the AWC. In addition, $0.30 \mathrm{~m}$ deep soil pits were opened around the site to allow better drainage and to reduce water inlet likelihood. Irrigation was performed using drip line. Sequential water balance validation tests were applied to samples from both soils.

Yield, oil content, oil yield, the mean number of grains per head, thousand-grain weight, mean head diameter, and 
fatty acid profile of the sunflower oil were analyzed after plant maturation and harvest. Second crop season data from 2015 were used in the analysis because of the damage suffered by plants subjected to water deficit near the anthesis in Santa Maria in the second crop season of 2014. Oil extraction was performed by the Soxhlet method. Oil was extracted for eight consecutive hours and petroleum ether was used as solvent in the process. For the fatty acid profile analysis, oil extraction was carried out by the cold method (Brum et al., 2009) to avoid any change in such profile under the high temperature demanded by the Soxhlet method. Esterification was performed and the fatty acid profile was analyzed by gas chromatography. Results were subjected to analysis of variance and the means were compared by the Tukey test ( $\mathrm{p} \leq 0.05)$.

\section{Results AND Discussion}

Both the yield (Table 1) and the yield components (Table 2) showed differences depending on water availability condition, sowing date and soil class. Yield was higher in the control treatment, because it also showed the highest thousand-grain weight, number of grains per head and head diameter $(\varnothing)$. Water surplus and deficit are responsible for a significant yield reduction. In addition, the main crop season showed a higher yield than the second crop season, mainly in the control treatment. This result repeats for the thousand-grain weight, number of grains per head and head diameter (Table 2).

Soil class also had great importance for yield, mainly in the water deficit treatment, where differences were observed (Table 1). The yields obtained for the water deficit decreases
$65.3 \%$ in Oxisol and $43.6 \%$ in Ultisol, compared with the control treatment.

The yield reached $5192.7 \mathrm{~kg} \mathrm{ha}^{-1}$ in the main crop season, $485.4 \mathrm{~kg} \mathrm{ha}^{-1}$ higher than the yield recorded for sunflower grown under optimal irrigation conditions in Iran (Gholinezhad \& Sajedi, 2012). However, water deficit strongly reduced yield as a response to the reduced number of grains per head and grain weight (Karam et al., 2007).

Although yield was significantly reduced by water stress, it is not possible to consider this result as totally negative. The water deficit treatment showed yields higher than $2400 \mathrm{~kg} \mathrm{ha}^{-1}$ in Ultisol and $1500 \mathrm{~kg} \mathrm{ha}^{-1}$ in Oxisol, even with no rain water intake for approximately 40 consecutive days and with water deficit until harvest.

According to Rosolem et al. (1999), root depth is greater in sandy soil than in clayey soils, whose texture exceeds $40 \%$ clay, because these soils offer great resistance to root penetration. In addition, clayey soils retain more water under restricted availability, because they have high wilting point, which reduces soil AWC. Water deficit was intensified earlier in Oxisol leading to lower water storage than in Ultisol, and it resulted in lower yield. Plants exposed to water deficit grown in Ultisol recorded yield 40 to $31 \%$ higher in the main crop season and in the second crop season, respectively, than plants subjected to water deficit in Oxisol.

Despite the stress conditions, mean sunflower production exceeded the Brazilian average of the last two years (1438.4 $\left.\mathrm{kg} \mathrm{ha}^{-1}\right)$, 2015/16 and 2016/17 crops (CONAB, 2017). According to Garofalo \& Rinaldi (2015), sunflower plants have the potential to maintain satisfactory grain yield even at reduced water supply.

Table 1. Yield $\left(\mathrm{kg} \mathrm{ha}^{-1}\right)$ of sunflower grown in main crop season (Sept. 6, 2013 and 7, 2013) and in the second crop season (Jan. 6, 2015 and 7, 2014), in an Ultisol in Santa Maria, RS state, Brazil and in an Oxisol in Panambi, RS state, Brazil, respectively

\begin{tabular}{|c|c|c|c|c|c|c|c|c|c|}
\hline \multicolumn{3}{|c|}{ Sowing date $x$ Soil class } & \multicolumn{3}{|c|}{ Sowing date $\mathrm{x}$ Water regime } & \multicolumn{4}{|c|}{ Soil class $\mathrm{x}$ Water regime } \\
\hline & Ultisol & Oxisol & & Main season & Second season & & Ultisol & Oxisol & Mean \\
\hline Main season & $3905.1 \mathrm{a}$ & $3466.0 \mathrm{a}$ & Control & $5192.7 \mathrm{a}$ & $3722.1 \mathrm{a}$ & Control & $4352.3 \mathrm{a}$ & $4573.5 \mathrm{a}$ & $4462.9 \mathrm{a}$ \\
\hline Second season & $2940.3 b$ & $2781.0 \mathrm{~b}$ & Surplus & $3892.5 b$ & $2780.2 b$ & Surplus & $3460.9 \mathrm{~b}$ & $3211.8 b$ & $3336.3 b$ \\
\hline & & & Deficit & $1971.5 \mathrm{C}$ & $2068.8 \mathrm{C}$ & Deficit & $2455.0 \mathrm{C}$ & $1585.3 \mathrm{c}$ & 2020.2 c \\
\hline Mean & $3422.7 \mathrm{~A}$ & $3123.5 \mathrm{~B}$ & & $3685.6 \mathrm{~A}$ & 2860.7 B & & & & \\
\hline
\end{tabular}

Mean $\left(\mathrm{kg} \mathrm{ha}^{-1}\right)-3273.1$

CV (\%) - 7.7

Means followed by the same letter in the column (lowercase letters) and in the row (capital letters) did not differ by Tukey test (p $\leq 0.05$ ). Treatments: Control - Control (soil moisture between 75 and $100 \%$ of the AWC); Surplus - Water surplus (soil moisture at $90 \%$ of AWC and saturation); Deficit - Water deficit (soil moisture between 40 and $60 \%$ of AWC). The yield was adjusted to $13 \%$ moisture in the seeds; AWC - Available water capacity

Table 2. Thousand-grain weight (TGW), grain number per head (GN/Head) and head diameter ( $\varnothing$ ) of sunflower grown in main crop season (Sept. 6, 2013 and 7, 2013) and in the second crop season (Jan. 6, 2015 and 7, 2014), in an Ultisol in Santa Maria, RS state, Brazil and in an Oxisol in Panambi, RS state, Brazil, respectively

\begin{tabular}{|c|c|c|c|c|c|c|c|c|c|c|c|c|c|c|c|c|c|c|}
\hline \multirow{2}{*}{$\begin{array}{l}\text { Water } \\
\text { regime }\end{array}$} & \multicolumn{6}{|c|}{ TGW (g) } & \multicolumn{6}{|c|}{ GN/Head } & \multicolumn{6}{|c|}{ Ø (cm) } \\
\hline & \multicolumn{2}{|c|}{ Ultisol } & Oxiso & & \multicolumn{2}{|c|}{ Mean } & \multicolumn{2}{|l|}{ Ultisol } & \multicolumn{2}{|c|}{ Oxisol } & \multicolumn{2}{|l|}{ Mean } & \multicolumn{2}{|c|}{ Ultisol } & \multicolumn{2}{|c|}{ Oxisol } & \multicolumn{2}{|c|}{ Mean } \\
\hline & \multicolumn{18}{|c|}{ Main crop season } \\
\hline Control & 65.0 & $\mathrm{a}$ & 62.5 & a & & & 1805.1 & a & 1864.0 & $\mathrm{a}$ & & & 19.4 & $\mathrm{a}$ & 18.8 & $\mathrm{a}$ & & \\
\hline Surplus & 51.0 & b & 58.9 & $\mathrm{a}$ & 53.8 & $\mathrm{a}$ & 1791.5 & $\mathrm{a}$ & 1430.8 & b & 1444.7 & $\mathrm{a}$ & 17.5 & b & 16.5 & b & 17.1 & $\mathrm{a}$ \\
\hline \multirow[t]{2}{*}{ Deficit } & 43.6 & C & 41.7 & b & & & 1284.9 & b & 802.7 & C & & & 15.6 & C & 14.9 & C & & \\
\hline & \multicolumn{18}{|c|}{ Second crop season } \\
\hline Control & 50.9 & a & 60.8 & a & \multirow{5}{*}{48.9} & & 1545.4 & a & 1467.6 & $\mathrm{a}$ & \multirow{4}{*}{1275.8} & & 17.7 & $\mathrm{a}$ & 17.3 & $\mathrm{a}$ & \multirow{4}{*}{15.1} & \\
\hline Surplus & 42.9 & b & 51.4 & b & & b & 1511.6 & a & 1172.0 & b & & b & 16.2 & b & 15.2 & $b$ & & $\mathrm{~b}$ \\
\hline Deficit & 46.3 & $a b$ & 41.3 & C & & & 729.8 & $b$ & 918.0 & C & & & 12.7 & C & 11.9 & C & & \\
\hline Mean & 49.9 & B & 52.8 & $A$ & & & 1496.5 & A & 1224.1 & B & & & 16.5 & $A$ & 15.7 & B & & \\
\hline CV $(\%)$ & \multicolumn{5}{|c|}{7.83} & & \multicolumn{6}{|c|}{7.82} & \multicolumn{6}{|c|}{2.82} \\
\hline
\end{tabular}

Means followed by the same letter in the column (lowercase letters) and in the row (capital letters) did not differ by Tukey test (p $\leq 0.05)$. Treatments: Control - Control (soil moisture between 75 and $100 \%$ of the AWC); Surplus - Water surplus (soil moisture at $90 \%$ of AWC and saturation); Deficit - Water deficit (soil moisture between 40 and $60 \%$ of AWC); AWC - Available water capacity 
Thousand-grain weight and number of grains per head have great influence on yield (Table 2). Fewer grains per head and lower thousand-grain weight are obtained when sunflower is subjected to water deficit, although the reduction is also found when the plant is subjected to water surplus. Moreover, the second crop season showed more reduction in these variables than the main crop season, and it results in lower yield.

The oil content analysis did not evidence any interaction between factors, whereas oil yield showed significant interaction between water condition and sowing dates (Table 3 ). The best results were recorded for the main crop season, which had higher mean oil content and oil yield values. The control treatment showed the best oil content and oil yield results. Oil content in the control treatment was not different from that in the water surplus one. The water deficit treatment led to the lowest oil content, and this result was not different from that of the water surplus.

Oil yield marked the difference between treatments. The lowest value was recorded for water deficit (Table 3), mostly in the main crop season. Oil yield is the only link between yield and oil content. Therefore, the lowest oil yield was found in the water deficit treatment, which was followed by the water surplus treatment. The main crop season had the highest oil yield among crop seasons, although with no differences between soil classes.

According to Connor \& Sadras (1992), the reduced number of grains per head in sunflower plants subjected to water deficit is caused by low water potential for ovarian metabolism, which leads to poor development and to the formation of a large number of grains without endosperm. Water surplus also led to reduced yield, but such reduction did not surpass the reduction caused by water deficit.

Sunflower grown under water stress (deficit or surplus) tends to reduce the number of grains per head and the thousand-grain weight. The number of flowers in each head may be smaller when the plant is grown under stress conditions. Moreover, water stress reduces grain filling rates after anthesis, which explains the lower thousand-grain weight results (Connor \& Sadras, 1992). Cantagallo et al. (2004) reported that shading can reduce the number of grains per head and grain weight, and it also explains the lower thousand-grain weight in the second crop season, because the grain filling period culminates in less solar radiation availability. The sowing date and the water conditions are factors with significant influence on oil content. Later sowing date (Unger, 1980), water deficit (Flagella et al., 2002) and water surplus (Yasumoto et al., 2011) lead to oil content reduction.

The oil fatty acid profile (Table 4 ) analysis showed the presence of large amounts of linoleic acid (50.56\%) and oleic acid (39.09\%). The palmitic, stearic and behenic acids were found at concentrations of approximately 5.35, 3.85 and $0.73 \%$, on average, respectively, whereas the ratio of other fatty acids was lower than $0.1 \%$. These fatty acids showed no difference concerning the three factors, except for the palmitoleic acid,

Table 3. Oil content (\%) and oil yield $\left(\mathrm{kg} \mathrm{ha}^{-1}\right)$ of sunflower plants grown in main crop season (Sept. 6, 2013 and 7, 2013) and in the second crop season (Jan. 6, 2015 and 7, 2014), in an Ultisol in Santa Maria, RS state, Brazil and in an Oxisol in Panambi, RS state, Brazil, respectively

\begin{tabular}{|c|c|c|c|c|c|c|c|}
\hline \multirow{2}{*}{$\begin{array}{l}\text { Water } \\
\text { regime }\end{array}$} & \multirow{2}{*}{$\begin{array}{l}\text { Oil content } \\
(\%)\end{array}$} & \multirow{2}{*}{$\begin{array}{l}\text { Sowing } \\
\text { date }\end{array}$} & \multirow{2}{*}{$\begin{array}{c}\text { Oil content } \\
(\%)\end{array}$} & \multicolumn{4}{|c|}{ Oil yield $\left(\mathrm{kg} \mathrm{ha}^{-1}\right)$} \\
\hline & & & & Water regime & Main season & Second season & Mean \\
\hline Control & $46.4 \mathrm{a}$ & Main season & $43.8 \mathrm{a}$ & Control & $2294.3 \mathrm{a}$ & 1366.9 a & $1830.6 \mathrm{a}$ \\
\hline Surplus & $41.0 \mathrm{ab}$ & Second season & $38.4 \mathrm{~b}$ & Surplus & $1510.3 \mathrm{~b}$ & $912.4 \mathrm{~b}$ & $1211.3 \mathrm{~b}$ \\
\hline \multirow[t]{2}{*}{ Deficit } & $35.9 b$ & & & Deficit & $623.8 \mathrm{c}$ & $640.6 \mathrm{~b}$ & $632.2 \mathrm{c}$ \\
\hline & & & & Mean & $1476.1 \mathrm{~A}$ & $973.3 \mathrm{~B}$ & \\
\hline Mean & & 41.09 & & & & & \\
\hline CV (\%) & & 15.67 & & & & & \\
\hline
\end{tabular}

Means followed by the same letter in the column (lowercase letters) and in the row (capital letters) did not differ by Tukey test (p $\leq 0.05$ ). Treatments: Control - Control (soil moisture between 75 and $100 \%$ of the AWC); Surplus - Water surplus (soil moisture at $90 \%$ of AWC and saturation); Deficit - Water deficit (soil moisture between 40 and $60 \%$ of AWC); AWC - Available water capacity

Table 4. Fatty acid profile (\%) of sunflower plants grown in main crop season (Sep. 6, 2013 and 7, 2013) and in the second crop season (Jan. 6, 2015 and 7, 2014), in an Ultisol in Santa Maria, RS state, Brazil and in an Oxisol in Panambi, RS state, Brazil, respectively

\begin{tabular}{|c|c|c|c|c|c|c|c|c|c|}
\hline \multirow{2}{*}{$\begin{array}{l}\text { Fatty } \\
\text { Acids }\end{array}$} & \multicolumn{3}{|c|}{ Water regime } & \multicolumn{2}{|c|}{ Crop season } & \multicolumn{2}{|c|}{ Soil class } & Mean & CV \\
\hline & Control & Surplus & Deficit & Main & Second & Ultisol & Oxisol & \multicolumn{2}{|c|}{$(\%)$} \\
\hline Cao 6:0 & $0.06 \mathrm{a}$ & $0.07 \mathrm{a}$ & $0.09 \mathrm{a}$ & $0.09 \mathrm{a}$ & $0.06 \mathrm{a}$ & $0.06 \mathrm{a}$ & $0.08 \mathrm{a}$ & 0.07 & 68.78 \\
\hline Cai 8:0 & $0.08 \mathrm{a}$ & $0.09 a$ & $0.07 \mathrm{a}$ & $0.08 \mathrm{a}$ & $0.08 \mathrm{a}$ & $0.07 \mathrm{a}$ & $0.09 a$ & 0.08 & 42.92 \\
\hline Сар 10:0 & $0.03 \mathrm{a}$ & $0.03 \mathrm{a}$ & $0.04 \mathrm{a}$ & $0.03 \mathrm{a}$ & $0.04 \mathrm{a}$ & $0.03 \mathrm{a}$ & $0.04 \mathrm{a}$ & 0.03 & 70.41 \\
\hline Mir 14:0 & $0.09 a$ & $0.10 \mathrm{a}$ & $0.09 a$ & $0.09 a$ & $0.10 \mathrm{a}$ & $0.09 \mathrm{a}$ & $0.10 \mathrm{a}$ & 0.09 & 34.80 \\
\hline Pen 15:0 & $0.02 \mathrm{a}$ & $0.02 \mathrm{a}$ & $0.02 \mathrm{a}$ & $0.01 \mathrm{~b}$ & $0.02 \mathrm{a}$ & $0.02 \mathrm{a}$ & $0.02 \mathrm{a}$ & 0.02 & 24.10 \\
\hline Pal 16:0 & $5.28 b$ & $5.31 \mathrm{~b}$ & $5.47 \mathrm{a}$ & $5.50 \mathrm{a}$ & $5.21 \mathrm{~b}$ & $5.39 \mathrm{a}$ & $5.32 \mathrm{a}$ & 5.35 & 2.90 \\
\hline Ple $16: 1 n 7$ & $0.10 \mathrm{a}$ & $0.10 \mathrm{a}$ & $0.10 \mathrm{a}$ & $0.11 \mathrm{a}$ & $0.08 \mathrm{~b}$ & $0.11 \mathrm{a}$ & $0.08 \mathrm{~b}$ & 0.10 & 11.60 \\
\hline Ste 18:0 & $3.59 c$ & $3.77 \mathrm{~b}$ & $4.17 \mathrm{a}$ & $3.60 \mathrm{~b}$ & $4.08 \mathrm{a}$ & $3.57 \mathrm{~b}$ & $4.12 \mathrm{a}$ & 3.85 & 4.18 \\
\hline Ela $18: 1 n 9 t$ & $0.02 \mathrm{a}$ & $0.04 \mathrm{a}$ & $0.02 \mathrm{a}$ & $0.02 \mathrm{a}$ & $0.03 \mathrm{a}$ & $0.02 \mathrm{a}$ & $0.03 \mathrm{a}$ & 0.03 & 96.99 \\
\hline Ole 18:1 $1 \Delta 9$ & $37.39 \mathrm{~b}$ & $37.92 \mathrm{~b}$ & $41.96 \mathrm{a}$ & $41.98 \mathrm{a}$ & $36.21 \mathrm{~b}$ & $39.99 \mathrm{a}$ & $38.19 b$ & 39.09 & 7.15 \\
\hline Lin 18:2 & $52.63 \mathrm{a}$ & $51.83 \mathrm{a}$ & $47.20 \mathrm{~b}$ & $47.79 \mathrm{~b}$ & $53.32 \mathrm{a}$ & $49.93 \mathrm{a}$ & $51.19 \mathrm{a}$ & 50.56 & 5.25 \\
\hline Beh 22:0 & $0.69 \mathrm{~b}$ & $0.71 \mathrm{~b}$ & $0.77 \mathrm{a}$ & $0.69 \mathrm{~b}$ & $0.76 \mathrm{a}$ & $0.72 \mathrm{a}$ & $0.74 \mathrm{a}$ & 0.73 & 5.49 \\
\hline
\end{tabular}

Means followed by the same letter in the row did not differ by Tukey test ( $\mathrm{p} \leq 0.05)$; Caproic acid (Cao 6:0); Caprylic acid (Cai 8:0); Capric acid (Cap 10:0); Myristic acid (Mir 14:0); Pentadecanoic acid (Pen 15:0); Palmitic acid (Pal 16:0); Palmitoleic acid (Ple 16:1n7); Stearic acid (Ste 18:0); Elaidic acid (Ela 18:1n9t); Oleic acid (Ole 18:1 $\Delta$ 9); Linoleic acid (Lin 18:2) and Behenic acid (Beh 22:0). Treatments: Control - Control (soil moisture between 75 and 100\% of the AWC); Surplus - Water surplus (soil moisture at 90\% of AWC and saturation); Deficit - Water deficit (soil moisture between 40 and 60\% of AWC); AWC - Available water capacity 
which differed depending on the sowing date and soil class. The caproic, caprylic, capric, myristic, pentadecylic, palmitoleic and elaidic fatty acids showed mean total contents of $0.07,0.08$, $0.03,0.09,0.02,0.10$ and $0.03 \%$, respectively.

Crop season has great influence on sunflower oil composition. The main crop season showed higher oleic/ linoleic fatty acids ratios and it means that the second crop season produced more linoleic acid and less oleic acid than the main crop season, and these results may be related to air temperature during grain ripening.

The final grain filling and maturation periods in the main season crop happened in late December, when there were high air temperatures, whereas, by following the trend of normal weather, the same period happened in early April in the second season crop, when the temperature was milder.

Water deficit increases the content of oleic acid, fatty acid desaturation and saturated fatty acid formation. The palmitic and stearic acids are undesirable for nutritional quality purposes (Connor \& Sadras, 1992). These results are consistent with those found by Flagella et al. (2002) and Sezen et al. (2011).

The water surplus treatment differed from the control treatment for the Stearic Acid, which also showed increased content (Table 4). The water surplus conditions did not show a significant effect on the ratio of oleic/linoleic fatty acids, comparing to the control. Yasumoto et al. (2011) found similar results. Presumably, this result is explained by the water surplus level, which was not a continuous waterlogging in the current study.

Air temperature has influence on fatty acids. High air temperatures during maturation were recorded in the main crop season and they led to increased oleic acid contents in sunflower, as described previously by Unger (1980). In addition, solar radiation also has influence on the quality of the oil because the higher the interception of solar radiation in different crops, the larger the amount of oleic acid, although it is not significant for sunflower plants (Izquierdo et al., 2009).

\section{Conclusions}

1. Water deficit decreases sunflower yield, yield components and oil content, besides increasing the oleic/linoleic ratio in oil.

2. The water surplus applied by intermittent soil saturation affects sunflower oil quality and decreases yield, yield components and oil content.

3. Sunflower shows greater yield and yield component results in Ultisol than in Oxisol under water deficit.

4. Sunflower sown in the main crop season increases yield, yield components and oil content in comparison to the second crop season, but, on the other hand, it increases oleic/linoleic fatty acids ratio.

\section{Literature Cited}

Allen, R. G.; Pereira, L. S.; Raes, D.; Smith, M. Crop evapotranspiration: Guidelines for computing crop water requirements. Rome: FAO, 1998. 300p.

Brum, A. A. S.; Arruda, L. F. de; Arce, M. A. B. R. Métodos de extração e qualidade da fração lipídica de matérias-primas de origem vegetal e animal. Química Nova, v.32, p.849-854, 2009. http:// dx.doi.org/10.1590/S0100-40422009000400005
Cantagallo, J. E.; Medan, D.; Hall, A. J. Grain number in sunflower as affected by shading during floret growth, anthesis and grain setting. Field Crops Research, v.85, p.191-202, 2004. https://doi. org/10.1016/S0378-4290(03)00160-6

CONAB - Companhia Nacional Abastecimento. Série histórica de produção e área plantada: Safras 1976/1977 a 2017/2018. Brasília: CONAB, 2017. 3p.

Connor, D. J.; Sadras, V. O. Physiology of yield expression in sunflower. Field Crops Research, v.30, p.333-389, 1992. https:// doi.org/10.1016/0378-4290(92)90006-U

Dourado Neto, D.; García, A. y G.; Fancelli, A. L.; Frizzone, J. A.; Reichardt, K. Balance hídrico cíclico y secuencial: Estimación de almacenamiento de agua en el suelo. Scientia Agrícola, v.56, p.537546, 1999. http://dx.doi.org/10.1590/S0103-90161999000300005

Flagella, Z.; Rotunno, T.; Tarantino, E.; Caterina, R. di; Caro, A. de. Changes in seed yield and oil fatty acid composition of high oleic sunflower (Helianthus annuus L.) hybrids in relation to the sowing date and the water regime. European Journal of Agronomy, v.17, p.221-230, 2002. https://doi.org/10.1016/S1161-0301(02)00012-6

Garofalo, P.; Rinaldi, M. Leaf gas exchange and radiation use efficiency of sunflower (Helianthus annus L.) in response to different deficit irrigation strategies: From solar radiation to plant growth analysis. European Journal of Agronomy, v.64, p.88-97, 2015. https://doi. org/10.1016/j.eja.2014.12.010

Gholinezhad, E.; Sajedi, N. Evaluation of water deficit stress effects, different rates of nitrogen and plant density on remobilization, current photosynthesis and grain yield in sunflower var. Iroflor. World Applied Sciences Journal, v.19, p.650-658, 2012.

Grassini, P.; Indaco, G. V.; Pereira, M. L.; Hall, A. J.; Trápani, N. Responses to short-term waterlogging during grain filling in sunflower. Field Crops Research, v.101, p.352-363, 2007. https:// doi.org/10.1016/j.fcr.2006.12.009

Heldwein, A. B.; Loose, L. H.; Lucas, D. D. P.; Hinnah, F. D.; Bortoluzzi, M. P.; Maldaner, I. C. Yield and growth characteristics of sunflower sown from August to February in Santa Maria, RS. Revista Brasileira de Engenharia Agrícola e Ambiental, v.18, p.908-913, 2014. http://dx.doi.org/10.1590/1807-1929/agriambi. v18n09p908-913

Izquierdo, N. G.; Aguirrezábal, L. A. N.; Andrade, F. H.; Geroudet, C.; Valentinuz, O.; Iraola, M. P. Intercepted solar radiation affects oil fatty acid composition in crop species. Field Crops Research, v.114, p.66-74, 2009. https://doi.org/10.1016/j.fcr.2009.07.007

Jalilian, J.; Modarres-Sanavy, S. A. M.; Saberali, S. F.; Sadat-Asilan, K. Effects of the combination of beneficial microbes and nitrogen on sunflower seed yields and seed quality traits under different irrigation regimes. Field Crops Research, v.127, p.26-34, 2012. https://doi.org/10.1016/j.fcr.2011.11.001

Karam, F.; Lahoud, R.; Masaad, R.; Kabalan, R.; Breidi, J.; Chalita, C.; Rouphael, Y. Evapotranspiration, seed yield and water use efficiency of drip irrigated sunflower under full and deficit irrigation conditions. Agricultural Water Management, v.90, p.213-223, 2007. https://doi.org/10.1016/j.agwat.2007.03.009

Righi, E. Z.; Heldwein, A. B.; Maldaner, I. C.; Lucas, D. D. P.; Stüker, P. E. Balance of longwave radiation employing the rate of solar radiation for Santa Maria, Rio Grande do Sul, Brazil. Revista Ciência Agronômica, v.46, p.29-37, 2015. http://dx.doi. org/10.1590/S1806-66902015000100004 
Rosolem, C. A.; Fernandez, E. M.; Andreotti, M.; Crusciol, C. A. C. Crescimento radicular de plântulas de milho afetado pela resistência do solo à penetração. Pesquisa Agropecuária Brasileira, v.34, p.821-828, 1999. http://dx.doi.org/10.1590/S0100204X1999000500013

Sezen, S. M.; Yazar, A.; Tekin, S. Effects of partial root zone drying and deficit irrigation on yield and oil quality of sunflower in a Mediterranean environment. Irrigation and Drainage, v.60, p.499508, 2011. https://doi.org/10.1002/ird.607
Spinelli, D.; Jez, S.; Basosi, R. Integrated environmental assessment of sunflower oil production. Process Biochemistry, v.47, p.15951602, 2012. https://doi.org/10.1016/j.procbio.2011.08.007

Unger, P. W. Planting date effects on growth, yield, and oil of irrigated sunflower. Agronomy Journal, v.72, p.914-916, 1980. doi:10.2134/ agronj1980.00021962007200060012x

Yasumoto, S.; Terakado, Y.; Matsuzaki, M.; Okada, K. Effects of high water table and short-term flooding on growth, yield, and seed quality of sunflower. Plant Production Science, v.14, p.233-248, 2011. http://doi.org/10.1626/pps.14.233 